\title{
Radioactivity Secreted in the Stomach Cavity after I-125 Labeled Synthetic Human Gastrin Administration to Rats $^{\dagger}$
}

\author{
Tatsuya Motoki, Yoshihisa Kato, Kazuo KamiI, \\ Tohru Migita, Haruo KAMEdA and Satoru MURAO \\ The 2nd Department of Internal Medicine, Faculty \\ of Medicine, Tokyo University \\ Received January 19, 1974
}

It is necessary for the elucidation of mechanism of gastric acid secretion to investigate the [behavior of gastrin in the body. The authors reported previously') that a considerable amount of radioactivity was observed along the inner layer of the glandular stomach and in the stomach cavity in a whole body autoradiography of rats which were injected ${ }^{125} \mathrm{I}$-labeled synthetic human gastrin ( ${ }^{125}$ I-SHG). In this report, the radioactivity secreted in the stomach cavity after the injection of ${ }^{125}$ I-SHG to rats was studied.

\section{Material and Method}

Synthetic human gastrin I (I.C.I.) was labeled with ${ }^{125} \mathrm{I}$ by the method of Hunter \& Greenwood ${ }^{2}$, and the labeled product was purified with Sephadex G-10 and G-50 columns. Specific activity was $770 \mu \mathrm{Ci} / \mu \mathrm{g}$.

Three Wistar male rats weighing about $250 \mathrm{~g}$ were used. Anesthesia, operative procedure and titration of acid were carried out in the same manner as described by $\mathrm{Lai}^{3}$. The cavity of the stomach was perfused with $0.9 \%$ saline at a constant rate of $0.8 \mathrm{~m} l /$ minute. The gastric effluent was collected fractionally in 10-minute intervals. Two hundred $\mu \mathrm{Ci}$ of ${ }^{125}$ I-SHG was injected intravenously in several seconds. Each sample of the gastric perfusate was titrated and their radioactivity was counted in a well-type gamma counter. The samples were subjected to gel filtration of Sephadex
G-25 where the column size was $1.2 \times 60 \mathrm{~cm}$ and $0.1 M$ phosphate buffer ( $\mathrm{pH}$ 7.4) was used as eluent (elution speed $5 \mathrm{ml} /$ hour), and radioactivity of each fraction was counted. Further, the samples were subjected to paper chromatography, in which Toyo filter paper No. 51A and 1:1-methanol:water were used, and radioactivity of the chromatogram was scanned with a chromatoscanner. ${ }^{125} \mathrm{I}-\mathrm{SHG},{ }^{125} \mathrm{I}-\mathrm{Na}$ and uracil (M.W. 112.1) were used as controls in the above procedures.

\section{Result}

The time course of acid output and radioactivity secreted in the stomach cavity in a rat is shown in Fig. 1. Remarkable increase of acid secretion was observed already in first 10-minute period after the ${ }^{125}$ I-SHG injection and the peak was seen in 10 20 minutes period. The acid secretion almost returned to basal level in $40 \sim 50$ minutes period and maintained the same level thereafter. On the other hand, radioactivity of the stomach perfusate increased rapidly in the early periods, showing a peak at 1.5 hours after the injection and then gradual decrease was seen. Same results were also obtained on the other rats.

†ラットに ${ }^{125} \mathrm{I}$ 標識ヒト合成ガストリンを注射後に 胃内腔へ分泌される放射能について：本木達也, 加藤善久, 上井一男, 右田徹, 亀田治男, 村尾覚 (東京大学医学部第二内科, 東京都文京区本郷) 


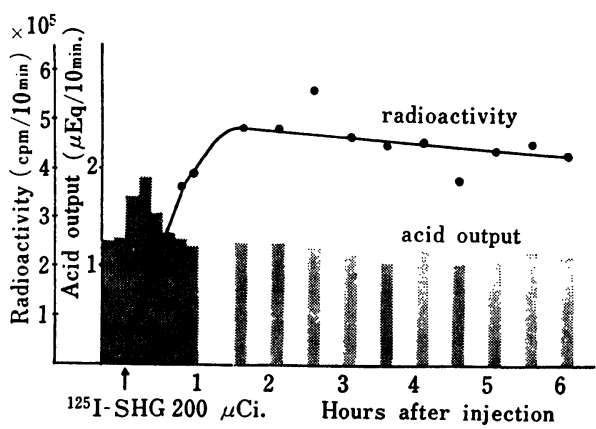

Fig. 1 Time course of acid output and radioactivity secreted in the stomach cavity in a rat.
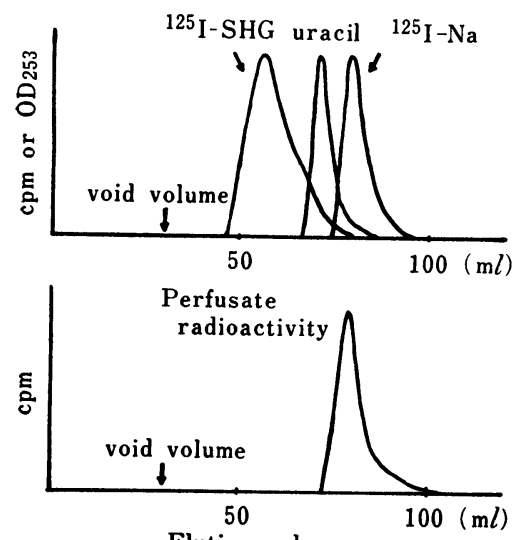

Elution volume

Fig. 2 Gel filtration of the stomach perfusate with Sephadex G-25.

The result of gel filtration study was shown in Fig. 2. Through all periods radioactivity of the perfusate was constantly eluted in one fraction, which appeared after uracil fraction and was in almost the same region as that of ${ }^{125} \mathrm{I}-\mathrm{Na}$. In the paper chromatogram radioactivity of the stomach perfusate showed one spot. The Rf values of the perfusate, ${ }^{125} \mathrm{I}-\mathrm{SHG}$ and ${ }^{125} \mathrm{I}-\mathrm{Na}$ were 0.55 , 0.64 and 0.71 , respectively. When the other developers were employed in paper chromatography, the spot of the perfusate was also distinguished from those of ${ }^{125}$ I-SHG and 125I-Na.

\section{Discussion}

The authors reported previously ${ }^{1)}$ that, after ${ }^{125}$-SHG 【was administered to rats, radioactive secretion was detected in the stomach cavity. In the present study too, the radioactivity of the stomach perfusate was confirmed. The radioactivity was, however, considered to be attributed neither to ${ }^{125}$ I-SHG nor to free iodine because the time course of its secretion was not parallel with that of acid secretion and because the radioactivity of the perfusate was considered to be different from both ${ }^{125}$ I-SHG and ${ }^{125} \mathrm{I}-\mathrm{Na}$ in gel filtration and paper chromatographic studies. Though the radioactivity of the perfusate and ${ }^{125} \mathrm{I}-\mathrm{Na}$ was eluted in fractions which appeared after uracil in gel filtration of Sephadex G-25, it was presumed to be attributed to some affinity of iodine to Sephadex. Therefore, radioactivity detected in the stomach cavity was considered to be of degradation products of ${ }^{125}$ I-SHG. As it was not determined whether this secretion was related to action mechanism of gastrin, further studies are necessary.

\section{Summary}

Radioactivity secreted in the stomach cavity of rats following ${ }^{125}$ I-labeled synthetic human gastrin injection was studied. It was considered to be caused by degradation products of ${ }^{125}$ I-labeled gastrin, but its significance in the action mechanism of gastrin was not determined.

\section{References}

1) Motoki, T., Kato, Y., Kamii, K., Migita, T., Kameda, H., Murao, S., Kamiyama, H. and Kurosaki, H.: A freezing whole body autography of ${ }^{125}$ I-labeled gastrin in rats, Radioisotopes, 23, 55 (1974)

2) Kirkharm, K.E. and Hunter, W.M.: Radioimmunoassay method, p. 54, Churchill Livingston, Edinburgh and London (1971)

3) Lai, K.S.: Studies on gastrin. Part 1: A method of biological assay of gastrin, Gut, 5, 327 (1964) 